\title{
Changing trends of river flows in the Upper Vistula Basin (East-Central Europe)
}

\author{
Marek Górnik ${ }^{1}$ (1)
}

Received: 6 June 2019 / Accepted: 8 January 2020 / Published online: 5 February 2020

(c) The Author(s) 2020

\begin{abstract}
The mean annual, winter half-year and summer half-year flows at 86 water level gauges in the Upper Vistula Basin in the years 1951-2015 were examined. The Ward's hierarchical cluster analysis was used for grouping sub-catchments in reference to the standardized aforementioned flows. Trends analysis was performed for each cluster of catchments in all combinations of periods not shorter than 20 years. Spatial distribution of clusters of catchments has been analysed according to geographical locations. There are observed different trends in distinguished groups of catchments, wherein the substantial differences concern long-term trends. Changes in trend direction in the years 1951-2015 were revealed, which indicate flow fluctuations. Presumably, physiographical heterogeneity of the Upper Vistula Basin is reflected in no unequivocal trends occurring in clusters of catchments. Some similarities were stated in short-term trends occurring in particular groups of catchments.
\end{abstract}

Keywords River runoff $\cdot$ Cluster analysis $\cdot$ Multitemporal trends $\cdot$ Mann-Kendall statistics $\cdot$ Poland

\section{Introduction}

Increase in air temperature and changes in precipitation have been noted in many areas but their effect on river flow has been difficult to pinpoint. Research on change detection in river flow has not revealed convincing and ubiquitous changes in Europe and worldwide, and there are no clear indications of significant trends of river flow at regional or large scales and there is as yet no evidence that the river flow in recent years is influenced directly by climate change (Kundzewicz ed. 2012; Madsen et al. 2014). Apart from climatic factors, there are other important components which may independently influence river flow variability, namely changes in land cover (reforestation or deforestation, urbanization), capacity of river channels, water intake for municipal, agricultural and industrial purposes, etc. (Slater et al. 2015). River runoff integrates the influence of this complex phenomenon over a watershed; hence, the analysis of long time series of river discharge datasets does not result in unequivocal satisfactory and expected results. From the other site, the search for trends (or

Marek Górnik

marek4891@poczta.fm

1 Institute of Geography and Spatial Management, Jagiellonian University, Gronostajowa Str. 7, 30-387 Cracow, Poland lack thereof) in river flow data series has become of scientific interest and practical importance in the last decades as it is essential for adaptation to climate change, in particular water management strategies (Adaptation... 2018).

There are a few studies on long-term river flow trends in Europe in last 200 years. Some trends are increasing but not statistically significant (Pekarova et al. 2003; Lindstrom and Bergstrom 2004). The average annual river flow in the second half of the twentieth and at the beginning of the twentyfirst centuries dropped in southern and south-eastern Europe and rose in the rest part of Europe (Stahl et al. 2012; Hannaford et al. 2013).

The analysis of long series of annual river flow showed no trends in Poland (Jokiel and Kożuchowski 1989; Miler 1999; Soja 2002; Stachý 2010), while in the second half of the twentieth century positive trends prevailed (Wrzesiński 2009). The re-analysis of the river flow trends for data on the second half of the twentieth and the beginning of the twenty-first centuries showed a decrease in river flows, with the exception of the Carpathian Mountains rivers where an increase in river flow was observed (Piniewski et al. 2018). Furthermore, numerous researchers point out to a decline in river flow in Europe in the summer halfyear and an increase in the winter half-year (Wrzesiński 2009; Stahl et al. 2010; Hannaford et al. 2013; Birsan et al. 2014; Piniewski et al. 2018). 
There is a region influencing considerably water resources for more than half of the territory of Poland, i.e., the Upper Vistula Basin. There is no detailed study reflecting contemporary trends in river flow with the exception of Piniewski et al.'s (2018) work related to the whole country area. The aim of the paper is an analysis of trends of average annual river flow in the Upper Vistula Basin in the years 1951-2015 and investigation into the spatial differentiation of trends. A multitemporal trend approach was applied to trend analysis, and trends were fitted to every possible combination of start and end years in the time record. This research may partly fill the gap in current research on changes in the river flow and additionally eliminate the impact of the length of data series on the value of calculated trend and is a response to the need for comprehensive studies of river flow trends (Hannaford et al. 2013; Piniawski et al. 2018). It is worth pointing out, however, that multitemporal trend approach does not replace the analysis of individual trends, but yet may be a complementary part of the study.

\section{Study area}

The area of the Upper Vistula Basin (at Zawichost gauge) drains a total of $50,731.8 \mathrm{~km}^{2}$ and covers a large part of the Southern Poland (Fig. 1). This area is about 25\% of the total Vistula drainage basin and is shared by Poland (91\%), Ukraine (5\%) and Slovakia (4\%). There are located three geographical regions: the Carpathian Mountains and their foreland, the Subcarpathian Basins and the Lesser Poland Uplands. The highest point within the watershed reaches the altitude of $2438 \mathrm{~m}$ a.s.l. in the Tatra Mountains, whereas the lower one is $134 \mathrm{~m}$ a.s.l. There are the highest annual precipitations in the Carpathian Mountains reaching $1700 \mathrm{~mm}$. This region includes headwater of most of the tributaries of the Upper Vistula River. Due to significant water resources, the Carpathian Mountains secure water for a number of regions far beyond their boundaries being an important water tower for the rest of the country (Pociask-Karteczka 2016). The share of the outflow from the Upper Vistula Basin in relation to the outflow from the whole Vistula basin amounts to $41 \%$, although it occupies only $25 \%$ of the entire Vistula River Basin (Chełmicki 1991). Hence, much of the flood risk in Poland is related to the Upper Vistula River Basin, and its right-bank tributaries significantly contribute to the total flood damage.

\section{Data and methods}

The study applied a multitemporal approach, whereby trends are fitted to every possible combination of start and end years in a record (McCabe and Wolock 2002; Hannaford et al. 2013). The datasets of 86 water gauge stations located on 50 rivers in the Upper Vistula Basin with long (1951-2015) hydrometric records were used in the analysis. The average daily river flow provided by the monitoring network system carried out by the Institute of Meteorology and Water Management-National Research Institute (IMGWBIP) was used in the study. The prevailing length of individual measurement series is 55 years except four records: Czarna-Raków, Prądnik-Ojców, Rudawa-Balice with 45-year series and the Nida-Czarna with a 50-year series.

In the first stage of the study, average annual flow values for each year $\left(\mathrm{SQ}_{\mathrm{Y}}\right)$, winter half-year $\left(\mathrm{SQ}_{\mathrm{W}}\right)$ and summer half-year $\left(\mathrm{SQ}_{\mathrm{S}}\right)$ for each catchment were calculated according to the classical formula for the arithmetic mean based on daily flow values, creating a data series for each catchment.

In the next step, based on the data series received for each catchment, multiannual average flow values for year $\left(\mathrm{SSQ}_{\mathrm{Y}}\right)$, winter half-year $\left(\mathrm{SSQ}_{\mathrm{w}}\right)$ and summer half-year $\left(\mathrm{SSQ}_{\mathrm{S}}\right)$ were calculated (also using the arithmetic mean formula).

Data series created from average annual flow values for each year $\left(\mathrm{SQ}_{\mathrm{Y}}\right)$, winter half-year $\left(\mathrm{SQ}_{\mathrm{W}}\right)$ and summer halfyear $\left(S_{S}\right)$ for each catchment were standardized by their multiannual mean value (respectively, by $\mathrm{SSQ}_{\mathrm{Y}}, \mathrm{SSQ}_{\mathrm{w}}$, $\mathrm{SSQ}_{\mathrm{S}}$ ), so that on all subsequent time series plots, annual values are shown as a proportion of the long-term mean in that indicator. To calculate normalized average flow values (STD SQ), the following formula was used:

$\mathrm{STD} \mathrm{SQ}=\frac{\mathrm{SQ}_{n}}{\mathrm{SSQ}}$

where $n$ is the certain year of multiannual period.

For the purpose of further calculations, the values obtained in the previous step were combined into annual data series $\left(\mathrm{S}_{-} S T D \mathrm{SQ}_{\mathrm{Y}}\right)$, winter half-year data series $\left(\mathrm{S}_{-}\right.$ STD $\mathrm{SQ}_{\mathrm{W}}$ ) and summer half-year data series ( $\mathrm{S}_{-} \mathrm{STD} \mathrm{SQ}_{\mathrm{S}}$ ).

Then, the catchments were clustered into a few regions broadly homogenous in terms of standardized annual ( $\mathrm{S}_{-}$ STD $\mathrm{SQ}_{\mathrm{Y}}$ ), standardized winter half-year $\left(\mathrm{S} \_S T D ~ S Q_{W}\right)$ and standardized summer half-year $\left(\mathrm{S} \_S T D ~ S Q_{S}\right)$ river flow series in the studied multiannual period. Cluster analysis in each of three groupings was carried out using the agglomerative hierarchical Ward method employing the Pearson's distance matrix $(1-r)$. Ward's method was used because it is one of the most popular and commonly used grouping methods in hydrology and meteorology (Hannaford et al. 2013; Wrzesiński and Sobkowiak 2018). It is worth noting that this method is often used due to simple mathematical properties and convenient graphical interpretation. The optimum number of clusters was determined on the basis of the geometry of the dendrogram and the plot of the binding distance. The number of identified groups was selected according to the highest homogeneity in a group in terms of interannual variability of average river flows. 


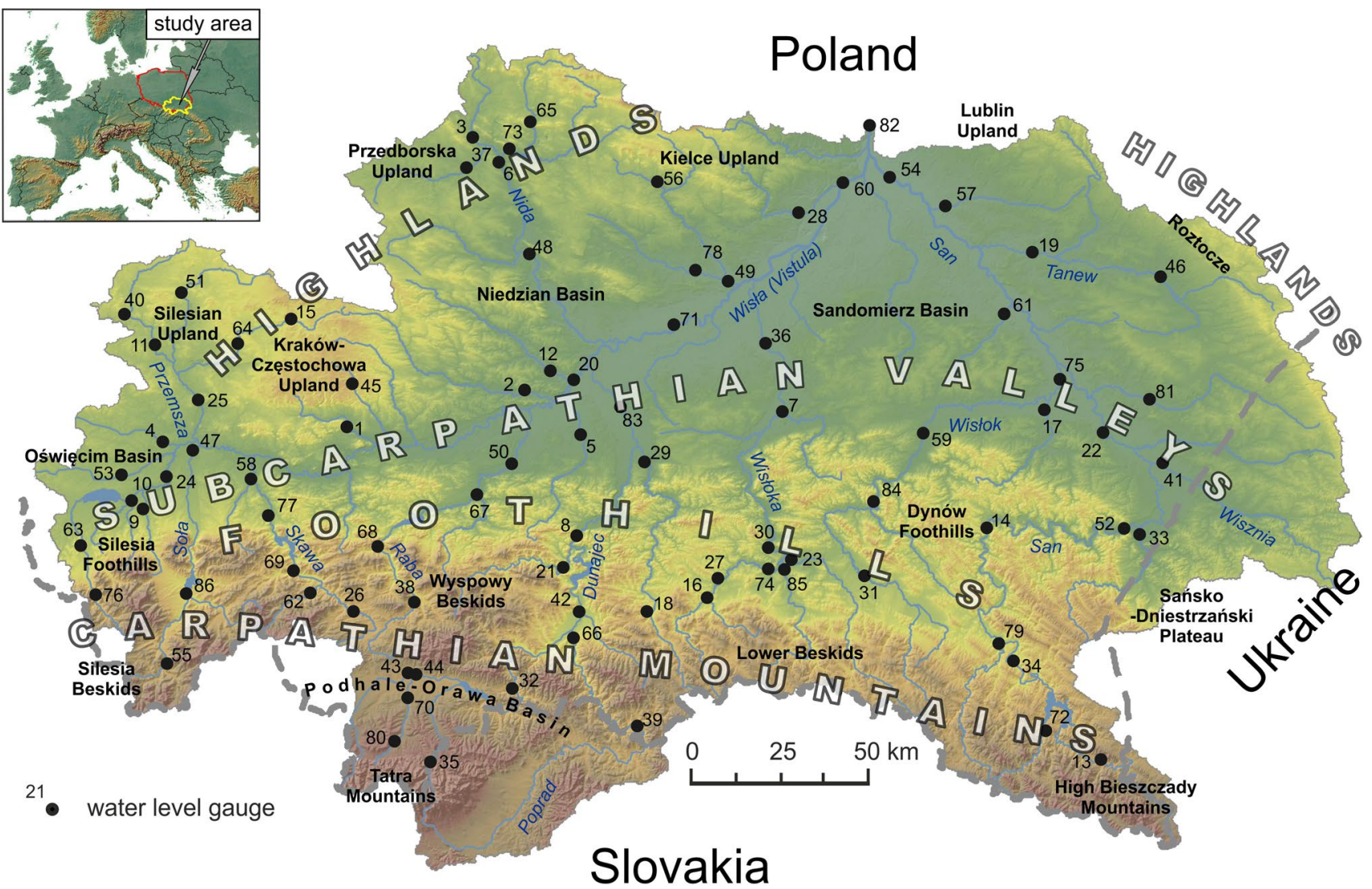

Fig. 1 Research area with locations of water level gauges in the Upper Vistula Basin. 1-the Rudawa at Balice, 2-the Szreniawa at Biskupice, 3-the Wierna Rzeka at Bocheniec, 4-the Gostynia at Bojszowy, 5-the Uszwica at Borzęcin, 6-the Nida at Brzegi, 7-the Wielopolka at Brzeźnica, 8-the Dunajec at Czchów, 9the Biała at Czechowice-Bestwina, 10-the Iłownica at Czechowice-Dziedzice, 11-the Brynica at Czeladź, 12-the Nidzica at Dobiesławice, 13-the San at Dwernik, 14-the San at Dynów, 15-the Biała Przemsza at Golczowice, 16-the Sekówka at Gorlice, 17-the Mleczka at Gorliczyna, 18-the Biała at Grybów, 19-the Tanew at Harasiuki, 20 - the Wisła at Jagodniki, 21-the Łososina at Jakubowice, 22-the San at Jarosław, 23-the Jasiołka at Jasło, 24 - the Wisła at Jawiszowice, 25-the Przemsza at Jeleń, 26-the Skawa at Jordanów, 27-the Ropa at Klęczany, 28-the Koprzywianka at Koprzywnica, 29-the Biała at Koszyce Wielkie, 30-the Wisłoka at Krajowiec, 31-the Wisłok at Krosno, 32-the Dunajec at Krościenko, 33-the Wiar at Krówniki, 34-the San at Lesko, 35-the Białka at Łysa Polana, 36-the Wisłoka at Mielec, 37-the Nida at Mniszek, 38-the Raba at Mszana Dolna, 39-the Poprad at Muszyna, 40-the Brynica at Namiarki, 41-the Wisznia at Nienowice, 42-the Dunajec at Nowy Sącz, 43-the Czarny

In the next step, the average values from standardized flows were calculated for separated groups of catchments separately for each year, each winter half-year and each summer half-year. As a result of this process, average values of standardized group flows were obtained for each year (GrSTD SQY), each winter half-year (GrSTD SQW) and each summer half-year (GrSTD SQS). These calculations
Dunajec at Nowy Targ, 44-the Dunajec at Nowy Targ-Kowaniec, 45-the Prąnik at Ojców, 46-the Tanew at Osuchy, 47-the Soła at Oświęcim, 48 - the Nida at Pińczów, 49-the Czarna at Połaniec, 50 - the Raba at Proszówki, 51-the Przemsza at Przeczyce, 52-the San at Przemyśl, 53-the Pszczynka at Pszczyna, 54-the San at Radomyśl, 55-the Soła at Rajcza, 56-the Czarna at Raków, 57the Bukowa at Ruda Jastkowska, 58-the Wieprzówka at Rudze, 59-the Wisłok at Rzeszów, 60-the Wisła at Sandomierz, 61-the Trzebośnica at Sarzyna, 62-the Skawica Dolna at Skawica, 63the Wisła at Skoczów, 64-the Biała Przemsza at Sławków, 65-the Bobrza at Słowik, 66-the Poprad at Stary Sącz, 67-the Stradomka at Stradomka, 68-the Raba at Stróża, 69-the Skawa at Sucha Beskidzka, 70 - the Biały Dunajec at Szaflary, 71-the Wisła at Szczucin, 72-the Solinka at Terka, 73-the Czarna Nida at Tokarnia, 74-the Ropa at Topoliny, 75-the Wisłok at Tryńcza, 76-the Wisła at Ustron-Obłaziec, 77-the Skawa at Wadowice, 78-the Wschodnia at Wilkowa, 79-the Osława at Zagórz, 80-the Cicha Woda at Zakopane-Harenda, 81-the Lubaczówka at Zapałów, 82-the Wisła at Zawichost, 83-the Dunajec at Żabno, 84-the Wisłok at Żarnowa, 85-the Wisłoka at Żółków and 86-the Soła at Żywiec

were carried out in each of the separated groups using the formula:

$\operatorname{GrSTD~SQ}_{n}=\frac{\sum \mathrm{STD} \mathrm{SQ}_{n}}{m}$

where $n$ is the certain year of multiannual period and $m$ is number of catchments in the group for given $n$. 
The final effect of the procedure, outlined above, was receiving for each group a series of annual data (S_GrSTD $\mathrm{SQ}_{\mathrm{Y}}$ ), of the winter half-year data $\left(\mathrm{S} \_\mathrm{GrSTD} \mathrm{SQ}_{\mathrm{W}}\right)$ and of

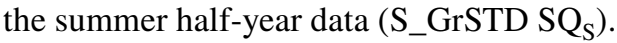

To check the quality of the data series match, there was determined a relationship between group-averages series

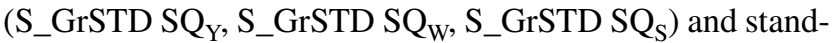
ardized average river flow series in particular catchments belonging to a given group $\left(\mathrm{S} \_S T D_{\text {SQ }} \mathrm{SQ}_{\mathrm{Y}}, \mathrm{S}_{-} \mathrm{STD} \mathrm{SQ}_{\mathrm{W}}, \mathrm{S}_{-}\right.$ STD $\mathrm{SQ}_{\mathrm{S}}$ ). The coefficient of determination calculated as the square of the Pearson correlation coefficient was used for this purpose. (Only positive correlation coefficients were considered.)

Trend analysis was performed to group-average river flows series (S_GrSTD SQ ${ }_{Y}, S_{-}$GrSTD SQ ${ }_{W}, S_{-}$GrSTD $\mathrm{SQ}_{\mathrm{S}}$ ). The nonparametric Mann-Kendall statistic was used to test for trends. It identifies monotonic increases or decreases in a time series by comparing between successive values. The Mann-Kendall test has been advocated for hydrological applications (Kundzewicz and Robson 2004). In order to remove the autocorrelation data from the series, the trend-free prewhitening (TFPW) method was used (Yue et al. 2002). According to McCabe and Wolock (2002), Mann-Kendall's statistics and its statistical significance were calculated for every possible combination of start and end years in the record 1951-2015. The minimum length of the calculation period was 20 years (Hannaford et al. 2013).

\section{Results}

\section{Annual river flow}

The result of cluster analysis is shown in Fig. 2. Most of the seven distinguished clusters of catchments are geographically coherent within the Upper Vistula Basin. The homogeneity of clusters $\left(Y_{\mathrm{I}}-Y_{\mathrm{VII}}\right)$ varies substantially. The standardized annual average flow series in particular basins (S_STD SQ ${ }_{Y}$ ) has been explained by the standardized group-average annual flow series $\left(\mathrm{S}_{-}\right.$GrSTD $\left.\mathrm{SQ}_{\mathrm{Y}}\right)$ from $53 \%$ (Biała Przemsza-Sławków) to 98\% (Brynica-Namiarki). A low homogeneity reveals the highest parts of the Upper Vistula Basin: The average annual river flow in the northern Tatra Mountains $\left(Y_{\mathrm{III}}\right)$ and the High Bieszczady Mountains catchments $\left(Y_{\mathrm{II}}\right)$ are poorly explained by the group-average river flow series $\left(\mathrm{S} \_\right.$GrSTD $\left.\mathrm{SQ}_{\mathrm{Y}}\right)$ - from 57 to $74 \%$, respectively-in comparison with other catchments within their groups.

There are clearly substantial differences between the directionality and magnitude of trends over time within particular clusters in the Upper Vistula Basin (Fig. 3). The $Y_{\mathrm{V}}$ upland cluster (Brynica River) is characterized by the predominant positive trends, while trends in the neighbouring group $Y_{\mathrm{VII}}$ are mostly negative. Negative trends are found also in the group $Y_{\mathrm{VI}}$ comprising the Oświęcim Basin, the Silesian Foothills and the Silesian Beskids Mountains. Within the Carpathian Mountains catchments (groups $Y_{\mathrm{II}}$ and $\left.Y_{\text {III }}\right)$, there is a contrast in trend directionality and positive trends prevail. Fluctuations between positive and negative trends over a range of periods remain in two groups $Y_{\mathrm{I}}$ and $Y_{\mathrm{IV}}$ representing mostly lowland catchments.

Trends in all groups are positive up to the second half of the 1980s. The decrease in river flow in the following years has weakened these trends, especially in mountain and foothill groups $\left(Y_{\mathrm{II}}, Y_{\mathrm{III}}\right)$ and upland group $\left(Y_{\mathrm{V}}\right)$. Within the rest of groups $\left(Y_{\mathrm{I}}, Y_{\mathrm{IV}}, Y_{\mathrm{VI}}, Y_{\mathrm{VII}}\right)$, there is a very strong contrast in trend directionality at the end of the 1980s, when trends reversed to negative ending in the end of the 1990s.

Trends after 2000 are mostly positive in the Carpathian catchments $\left(Y_{\mathrm{II}}, Y_{\mathrm{III}}, Y_{\mathrm{IV}}\right)$ and Brynica River catchment $\left(Y_{\mathrm{V}}\right)$ in contrast to $Y_{\mathrm{VI}}$ and $Y_{\mathrm{VII}}$ groups, where negative trends prevail. Trends in the group $Y_{\mathrm{I}}$ (eastern part of the Sandomierz Basin and a part of Roztocze) follow a very different pattern. After 2010, trends become weaker.

Trends starting between 1961 and 1981 are all negative up to the 1990s in all groups, and they remain negative in $Y_{\mathrm{IV}}, Y_{\mathrm{VI}}$ and $Y_{\mathrm{VII}}$. Groups $Y_{\mathrm{II}}, Y_{\mathrm{III}}, Y_{\mathrm{V}}$ show the change in trend directionality from negative to positive. In the $Y_{\mathrm{I}}$ group, no unambiguous flow trends were found.

For most of the groups, annual river flow trends after 1981 are predominantly positive to all end years. Negative trends over a range of periods after 1991 are common.

\section{Winter half-year river flow}

The eight groups of catchments on the basis of homogeneous hydrological behaviour on an S_STD SQ $_{W}$ using cluster analysis were formed. The clusters are relatively geographically coherent areas within the Upper Vistula Basin (Fig. 4). The standardized group averages of winter half-year flow series (S_GrSTD SQ ${ }_{W}$ ) explain from 33\% (Biała-Czechowice-Dziedzice) to $97 \%$ (Brynica-Namiarki) of standardized average winter half-year flow series in the catchments $\left(S_{-}\right.$STD $\left.\mathrm{SQ}_{\mathrm{W}}\right)$.

In the case of drainage catchments, the northern slopes of the Tatra Mountains and the Bieszczady Mountains (from 51 to 62\%) and catchments located within the Oświęcim Basin and the Silesian Foothills (from 33 to $64 \%$ ) in comparison with winter half-year flow in other catchments inside their group were poorly explained by their mean group $\left(S_{-}\right.$GrSTD $\left.\mathrm{SQ}_{\mathrm{W}}\right)$. A considerably low homogeneity reveals $W_{\text {VI }}$ and $W_{\text {VIII }}$ with catchments within, respectively, the Oświęcim Basin and the Silesian Foothills (from 33 to $64 \%$ ). 


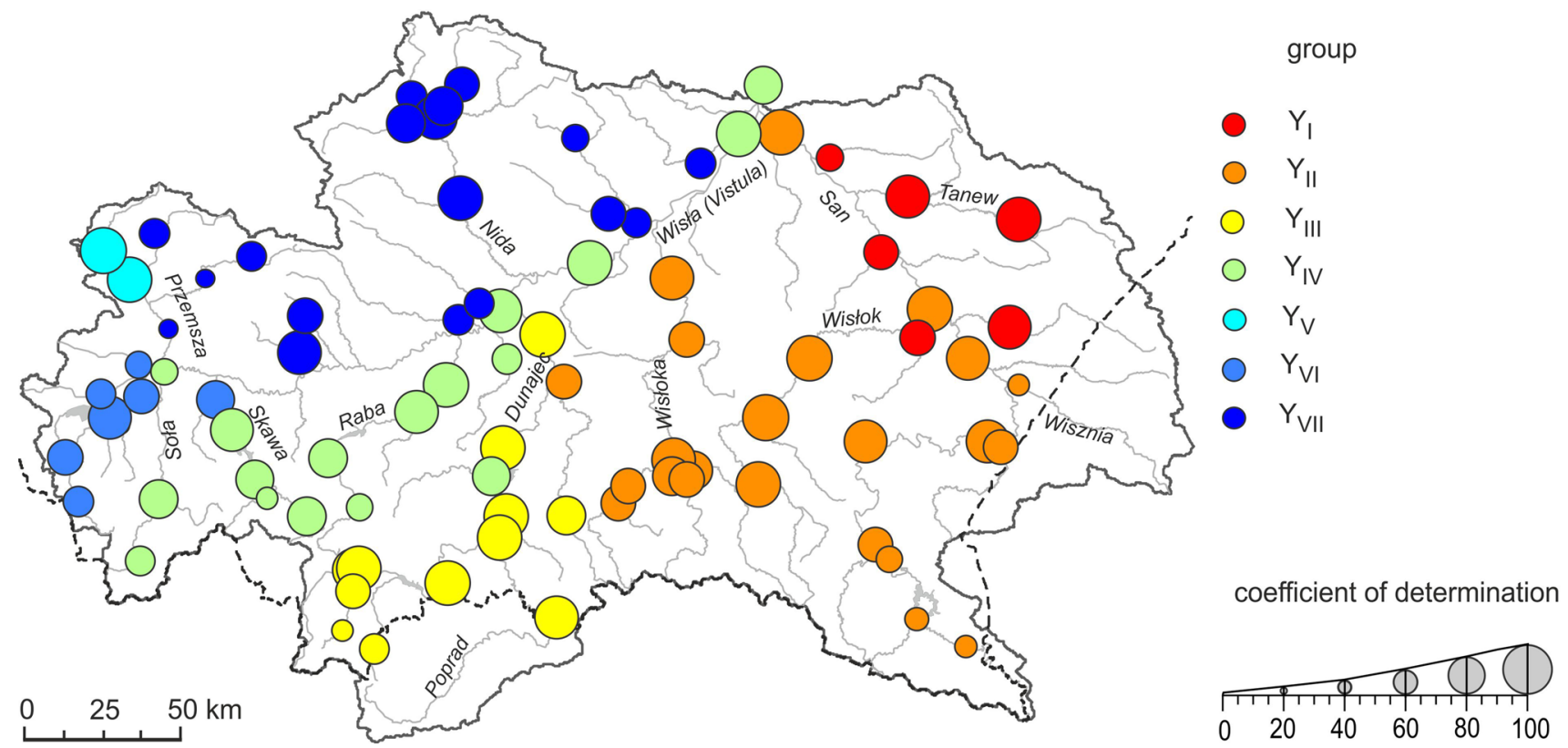

Fig. 2 Location of the catchments grouped into seven homogeneous clusters according to average annual river flow series ( $\mathrm{S}_{-} \mathrm{STD}$ SQ $\left.\mathrm{Y}_{\mathrm{Y}}\right)$ in the Upper Vistula Basin
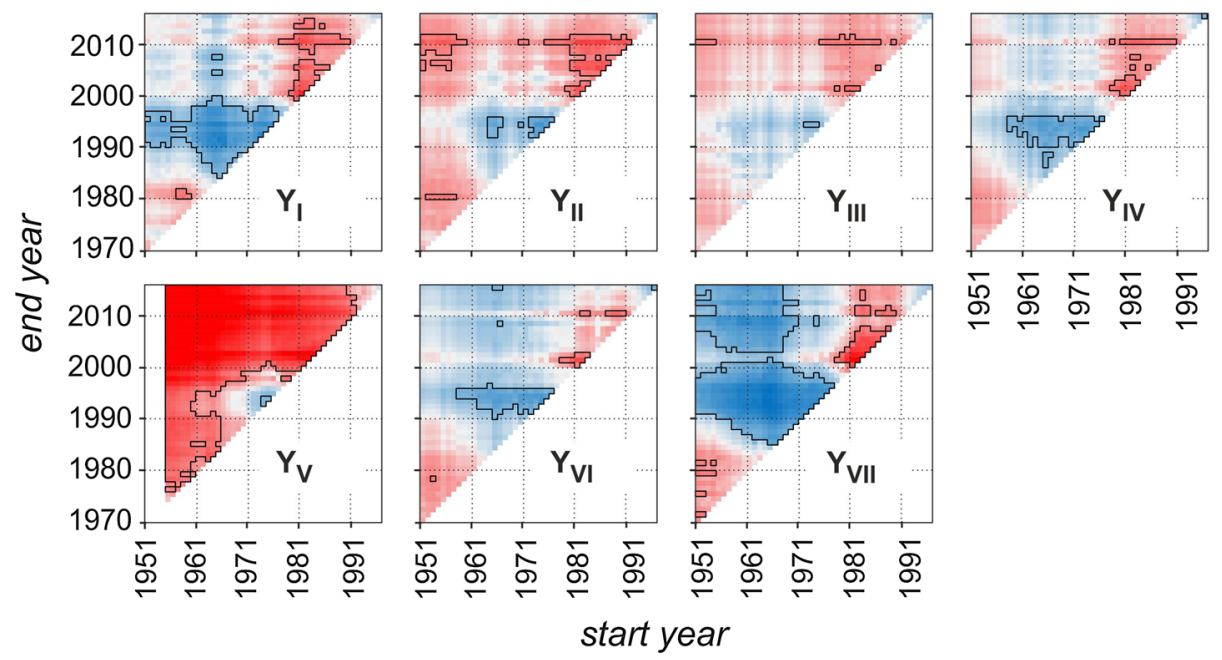

statistic Z

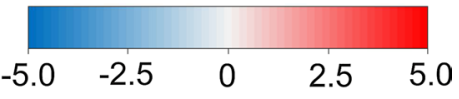

statistical significance $\alpha \leq 0.05$

Fig. 3 Multitemporal trend analysis for annual average river flow series (S_GrSTD $\mathrm{SQ}_{\mathrm{Y}}$ ). $X$-axis shows start year of trend, and $y$-axis shows end. The corresponding pixel is coloured according to the

Overall, the average winter half-year river flows follow various patterns in the period 1951-2015 (Fig. 5). Positive trends prevail in the Brynica River $\left(W_{\mathrm{I}}\right)$ and in the Carpathian catchments $\left(W_{\mathrm{II}}, W_{\mathrm{IV}}, W_{\mathrm{V}}\right)$. River flow in the catchments in upland area $\left(W_{\mathrm{VII}}, W_{\mathrm{VIII}}\right)$ and the Vistula River flow $\left(W_{\mathrm{VI}}\right)$ reveal decreasing trends. In the eastern parts of the Sandomierz Basin and Roztocze $\left(\mathrm{W}_{\mathrm{III}}\right)$, any dominating trend has been observed. resulting $\mathrm{Z}$ statistic (see legend), with red representing positive trends and blue representing negative trends

Positive trends prevail strongly up to the second half of the 1980s in all groups except $W_{\mathrm{V}}$ where this prevailing is less apparent. Trends remain positive in the following years in $W_{\mathrm{I}}$ and $W_{\mathrm{IV}}$ and become relatively weaker in $W_{\mathrm{II}}$ and $W_{\mathrm{V}}$, while there is a strong contrast in trend directionality over the time series in the groups $W_{\mathrm{III}}, W_{\mathrm{VI}}, W_{\mathrm{VII}}, W_{\mathrm{VIII}}$ (positive/negative). Trends starting in the end of the 1990s are positive within the $W_{\mathrm{I}}, W_{\mathrm{II}}, W_{\mathrm{IV}}$ and $W_{\mathrm{V}}$ groups. However, in 


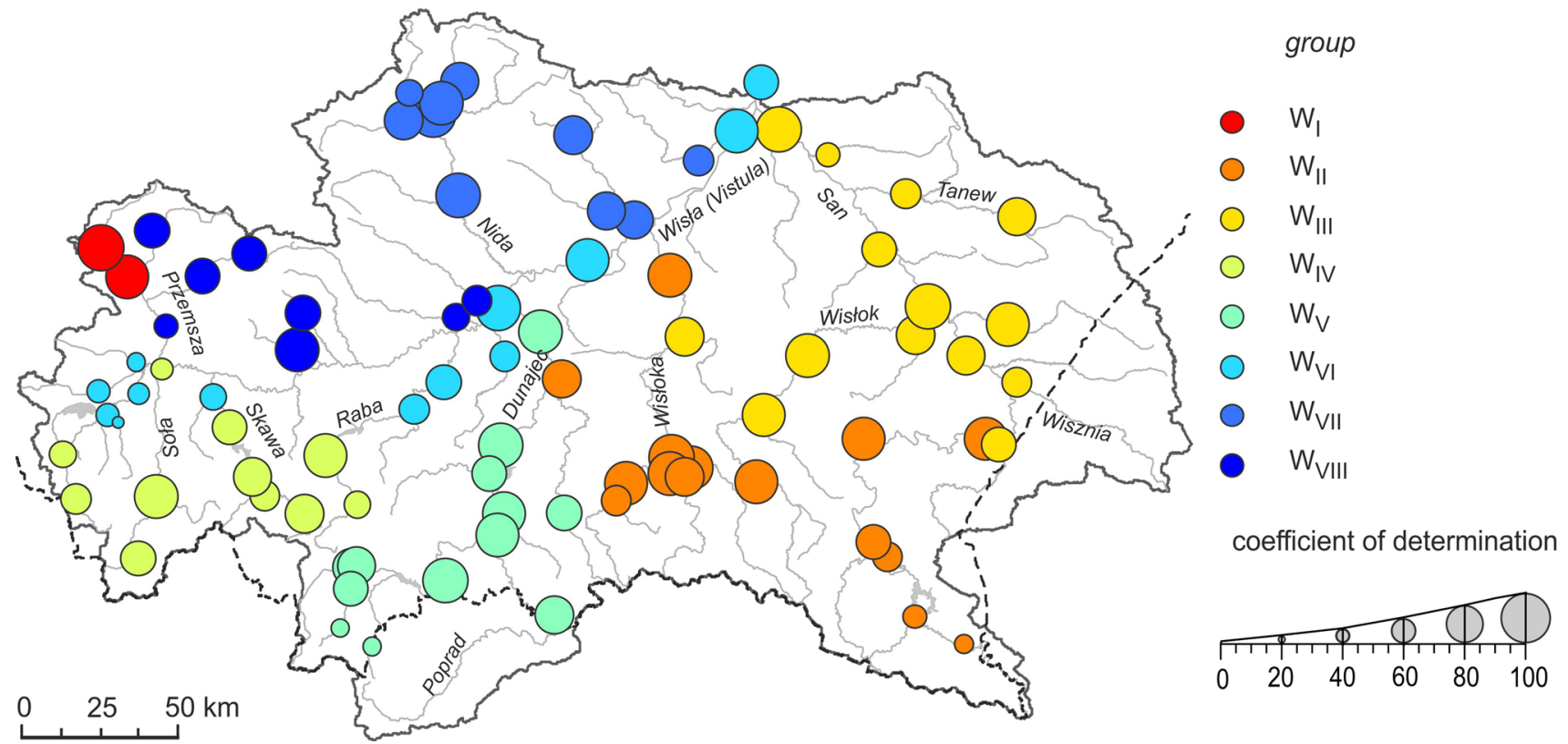

Fig. 4 Location of the catchments grouped into eight homogeneous clusters according to average winter half-year river flow series (S_STD $\mathrm{SQ}_{\mathrm{W}}$ ) in the Upper Vistula Basin
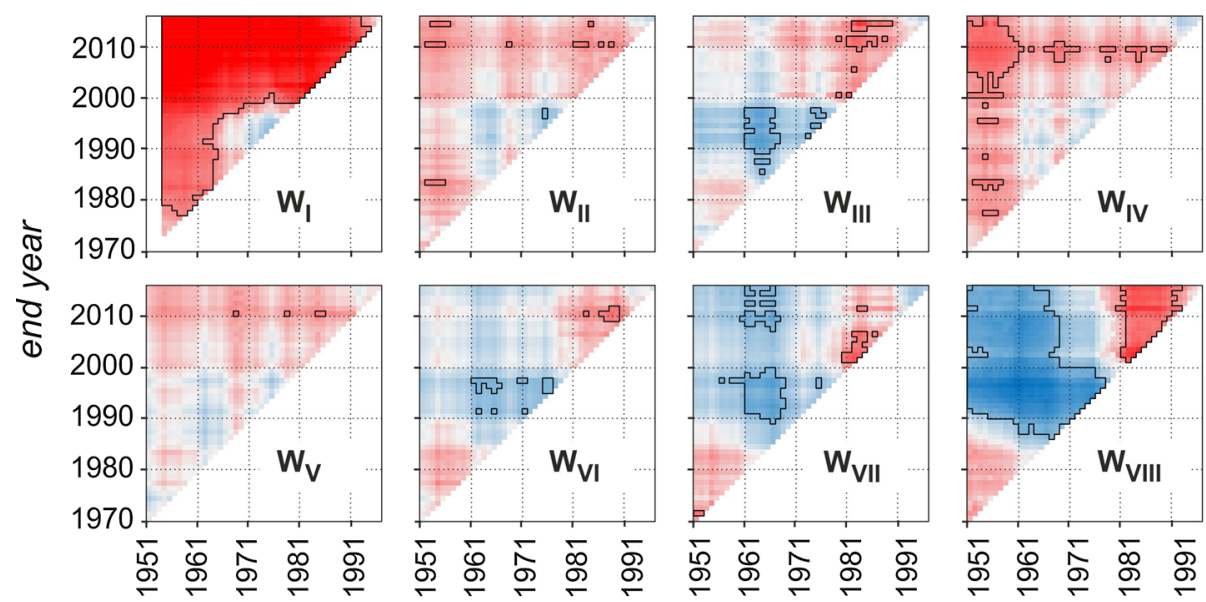

statistic Z

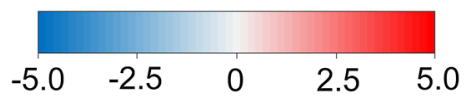

Multitemporal trend analysis for average winter half-year river flow series (S_GrSTD $\mathrm{SQ}_{\mathrm{W}}$ ). $X$-axis shows start year of trend, and $y$-axis shows end. The corresponding pixel is coloured according to

the group $W_{\text {III }}$, trend reverses (positive/negative). Negative trends are found in the groups $W_{\mathrm{VI}}, W_{\mathrm{VII}}, W_{\mathrm{VIII}}$ until 2015.

All trends starting in 1965-1981 and ending in 1985-2015 onwards are negative in $W_{\mathrm{VI}}, W_{\mathrm{VII}}, W_{\mathrm{VIII}}$. In the group $W_{\text {III }}$, trends remain negative to the end of the $1990 \mathrm{~s}$ and then change toward a positive one. There are fluctuations between positive and negative trends in the groups $W_{\mathrm{I}}$, $W_{\mathrm{II}}, W_{\mathrm{IV}}, W_{\mathrm{V}}$ until 2000; afterwards, positive trends increase.

the resulting $Z$ statistic (see legend), with red representing positive trends and blue representing negative trends

Trends starting between 1981 and 1991 are positive in all groups, while those starting after 1991 are mostly negative.

\section{Summer half-year river flow}

The catchments are clustered into eight groups, which are broadly homogenous in terms of variability of the summer half-year river flow (Fig. 6). Their geographical coherency 


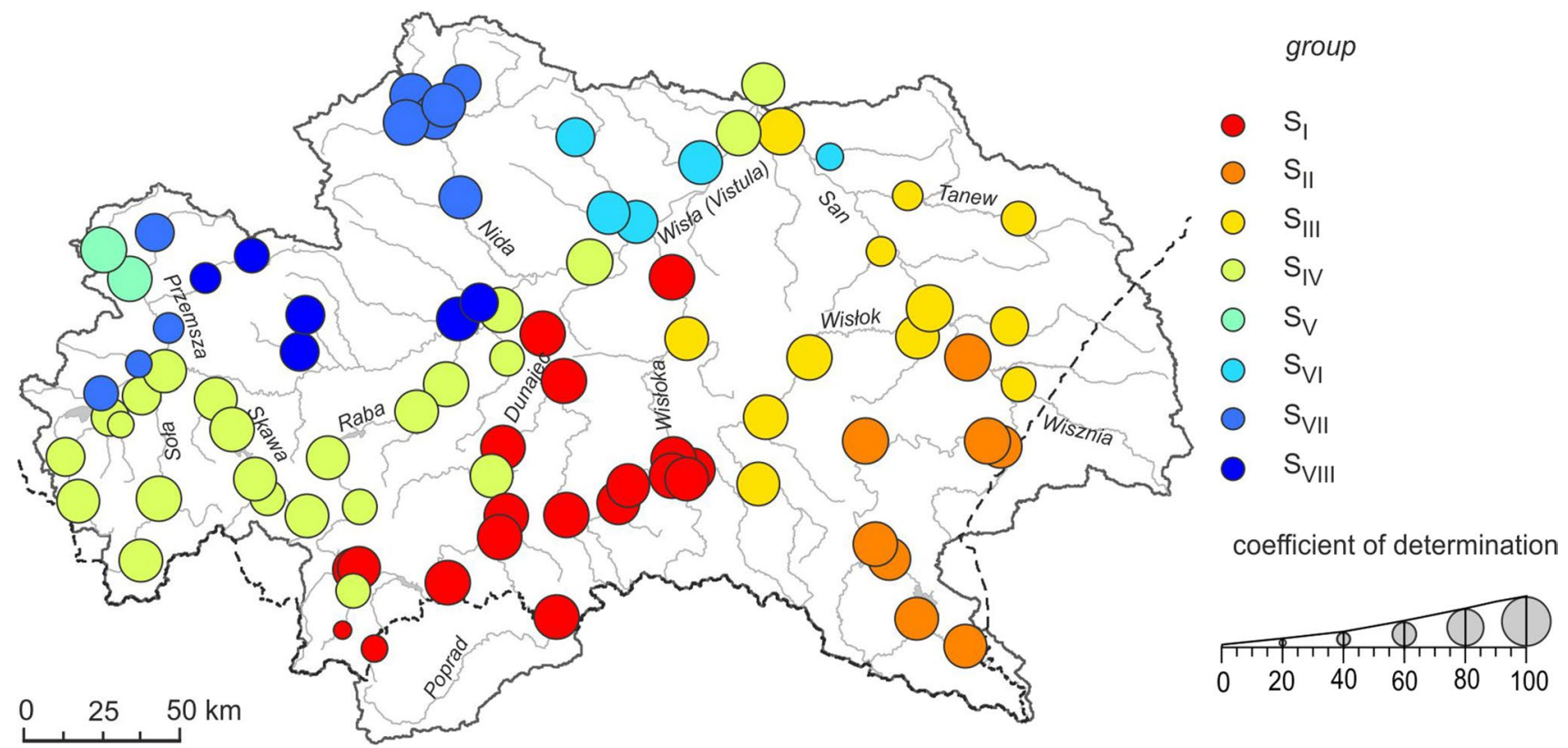

Fig. 6 Location of the catchments grouped into eight homogeneous clusters according to average summer half-year river flow series (S_STD $\mathrm{SQ}_{\mathrm{S}}$ ) in the Upper Vistula Basin

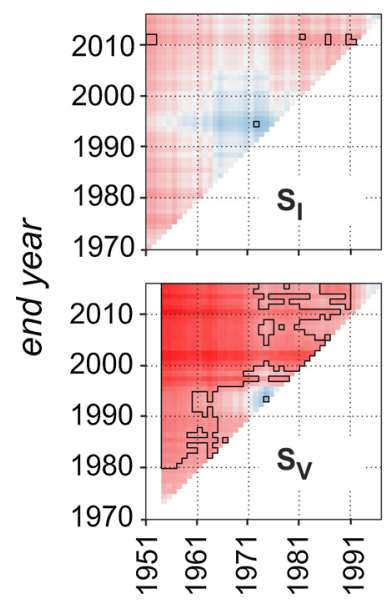

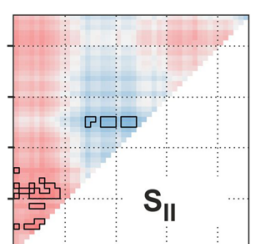

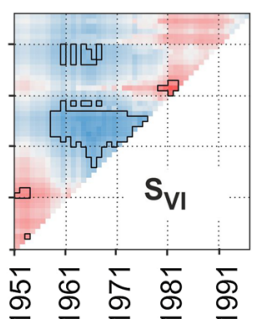

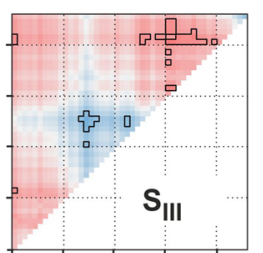

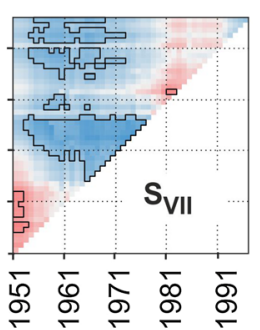

start year
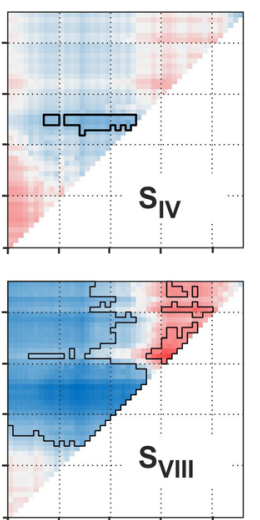

statistical significance $\alpha \leq 0.05$

statistic Z

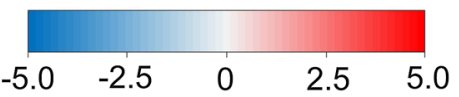

๘
Fig. 7 Multitemporal trend analysis for summer half-year average river flow series (S_GrSTD $\mathrm{SQ}_{\mathrm{S}}$ ). $X$-axis shows start year of trend, and $y$-axis shows end. The corresponding pixel is coloured according

is weaker than in the case of previous grouping. The homogeneity of the group $S_{\mathrm{I}}-S_{\mathrm{VIII}}$ differs substantially. The standardized group-average summer flow series (S_GrSTD $\mathrm{SQ}_{\mathrm{S}}$ ) explains from 55\% (Cicha Woda River-Zakopane-Harenda) to $99 \%$ (Brynica-Namiarki) standardized summer average flows series in catchments $\left(S_{-}\right.$STD $\left.S_{S}\right)$. A low homogeneity reveals the group $S_{\mathrm{I}}$ where the average summer river flow on the northern slopes of the Tatra Mountains has been poorly weakly explained-from 55\% to the resulting $\mathrm{Z}$ statistic (see legend), with red representing positive trends and blue representing negative trends

to $68 \%$ - by the standardized group —average summer halfyear flow series (S_GrSTD SQ S $_{\text {). }}$.

A very strong contrast in trend directionality over the average summer half-year river flow series has been found (Fig. 7). Trends in the catchments at the left-bank part of the Upper Vistula River $\left(S_{\mathrm{VI}}, S_{\mathrm{VII}}, S_{\mathrm{VIII}}\right)$ are predominantly negative except the Brynica $\left(S_{\mathrm{V}}\right)$. At the right-bank part of the Upper Vistula River basin $\left(S_{\mathrm{I}}, S_{\mathrm{II}}\right.$ and $\left.S_{\mathrm{III}}\right)$, positive trends 
prevail with the exception of the $S_{\text {IV }}$ group, which shows negative trends.

Trends in particular groups follow very different patterns. Trends of the summer half-year average river flow starting between 1951 and 1961 are positive for the groups $S_{\mathrm{I}}, S_{\mathrm{II}}$, $S_{\mathrm{III}}, S_{\mathrm{V}}$ and likewise for the groups $S_{\mathrm{IV}}, S_{\mathrm{VI}}$ and $S_{\mathrm{VII}}$ but only until the middle of the 1980s followed then by negative trends onwards. In the $S_{\mathrm{VIII}}$ until the mid-1980s, there have been no trends, while from the second half of the 1980s, negative trends have been observed.

Trends starting in between 1961 and 1981 were largely negative-up to 2015 in groups $S_{\mathrm{II}}, S_{\mathrm{IV}}, S_{\mathrm{VI}}, S_{\mathrm{VII}}$ and $S_{\mathrm{VIII}}$. For the $S_{\mathrm{I}}$ and $S_{\mathrm{III}}$, change in trends has been observed from negative to positive. The summer half-year average river flow in the group $S_{\mathrm{V}}$ is firmly dominated by positive trends. Negative trends occur merely in periods starting between 1971 and 1975 and ending in 1995 in this group.

\section{Discussion}

The results of multitemporal trend analysis for the annual, winter half-year and summer half-year averages river flow in the Upper Vistula Basin reveal substantial differences in trends in 1951-2015. It is consistent with previous studies carried out for rivers in Poland (Bartnik and Jokiel 1997; Fal and Bogdanowicz 2002; Wrzesiński 2009; Piniewski et al. 2018). Similar findings were observed by Hannaford et al. 2013 for other European rivers. Current research allows to identify in short river flow records an alternating occurrence of periods with positive and negative trends except two groups of catchments $W_{\mathrm{IV}}$ and $W_{\mathrm{V}}$. A shift from positive to negative trends in the first half of the 1960s and the end of the 1980s is typical for a multiannual temporal pattern of trends over a range of catchments (for the Brynica catchment: 1970s and 1980s, respectively). Apparent short-term trends indicate river flow fluctuations as a response of changing precipitation and air temperature associated with atmospheric circulation over Europe driven by large-scale patterns of climatic variability such as the NAO (Pociask-Karteczka et al. 2002-2003; Styszyńska and Tamulewicz 2005; Pociask-Karteczka 2006; Wrzesiński 2011; Wrzesiński and Paluszkiewicz 2011).

Long-term 40-50-year trends-primarily negative-are found in river flow catchments in the highland regions. The strong trends in summer half-year average flow prevail in the western part of highland region, while those in the eastern part are slightly weaker. There is a substantial difference in the Brynica River flow, which is dominated by strong positive trends in cases of both annual and half-year average flows. This catchment is strongly anthropogenically influenced primarily by Silesian coal mine activity. It was reported by Punzet (1973), Dynowska (1984) and Czaja
(1988) that pumped groundwater discharge to the river hinders a natural variability of river regime flow. Unsurprisingly, the group-average flow explains very poor average flows in such catchment as it is similar for the catchments on the northern slopes of the Tatras.

Clustering of catchments on the basis of variability of annual and winter half-year average river flows allowed to distinguish two regions in the Carpathian part of the Upper Vistula River basin: the western region and eastern region. This is unsurprising given the increase into the east a climatic continentality (Kożuchowski and Marciniak 1992) associated with predominance of snow over rain precipitation (Dynowska 1971; Ziemońska 1973). The western region spans to the upper part of the Biała Tarnowska River and the Dunajec River catchment, as Dobija (1981) and Chełmicki et al. (1999) indicated in their research on river runoff patterns and river runoff variability. In the case of the summer half-year average river flow, the border spans further to the east to the Wisłoka River (Ziemońska 1973) and to the Nida River in the northern part of uplands.

\section{Conclusions}

The conducted studies provide temporal patterns of trends and the evidence of regional hydrological response to the climate and anthropogenic activity in the Upper Vistula Basin.

Clustering of catchments on the basis of variability of annual, winter half-year and summer half-year average river flows allowed to distinguish three groups of catchments, i.e., $Y_{\mathrm{I}}-\mathrm{Y}_{\mathrm{VII}}, W_{\mathrm{I}}-\mathrm{W}_{\mathrm{VIII}}$ and $S_{\mathrm{I}}-S_{\mathrm{VIII}}$, geographically coherent in various degrees.

There are differences between groups of catchments in the directionality of trends over time for any one group of catchment.

Despite the presence of alternation in short-term trendsespecially evident in the case of average annual trendsa wide variation in long-term trends was observed in all groups. Their spatial distribution is closely related to the geographical regions. This may indicate a very strong impact of local environmental features on river runoff. This was pointed out in his works by Dobija and Dynowska (1975), Parajka et al. (2009), Wrzesiński (2017) and Wrzesiński and Sobkowiak (2018). Bezak et al. (2015) also referred to significance of the environment in identifying trends. Research conducted by Gutry-Korycka $(1996,1997)$ indicated lower resistance of lowland rivers to climatic changes compared to upland and mountain rivers. This analysis enables to conclude that two neighbouring groups of river catchments with different environmental conditions may react differently to climate changes and, therefore, have a different trend value.

The considerably higher coefficient of determination between the groups distinguished with average summer 
half-year flow likely indicates reasonably higher significance of climatic factors such as precipitation and air temperature than another geographical factors such as landforms and catchment storage on hydrology in the summer season. Further trends in river flow in the future will be dominated by increasing precipitation and air temperature as climate scenario projects for Poland. Therein, a significant increase in river flow will be noted in the winter season (Piniawski et al. 2016, 2017). Despite that, Romanowicz et al. (2016) signalized lack of tendencies in future river flow trends in two catchments in the Upper Vistula Basin and discrepancies in river flow projection for different climate scenarios.

The results of this study indicate considerable variability of trends in time according to the length of analysed time series. Extending or shortening of the time dataset causes strengthening or weakening of trend, or even change in the directionality of trend. Hence, an attempt to extrapolate river flow into past or future of such a selective viewpoint could easily be misleading, as mentioned by Svensson et al. (2006), Chen and Grasby (2009) and Hannaford et al. (2013). Also the underlying assumption of stationarity of river flow should be critically reviewed (Milly et al 2008, 2015; Piniawski et al 2018).

\section{Compliance with ethical standards}

Conflict of interest The corresponding author states that there is no conflict of interest.

Open Access This article is licensed under a Creative Commons Attribution 4.0 International License, which permits use, sharing, adaptation, distribution and reproduction in any medium or format, as long as you give appropriate credit to the original author(s) and the source, provide a link to the Creative Commons licence, and indicate if changes were made. The images or other third party material in this article are included in the article's Creative Commons licence, unless indicated otherwise in a credit line to the material. If material is not included in the article's Creative Commons licence and your intended use is not permitted by statutory regulation or exceeds the permitted use, you will need to obtain permission directly from the copyright holder. To view a copy of this licence, visit http://creativecommons.org/licenses/by/4.0/.

\section{References}

Adaptation to climate change (2018) European Commission. https:// ec.europa.eu/clima/policies/

Bartnik A, Jokiel P (1997) Zmiany odpływu na obszarze Polski w latach 1971-1990 w świetle analiz jednorodności szeregów przepływów rzek. Wiad IMGW 4:67-85

Bezak N, Horvat A, Šraj M (2015) Analysis of flood events in Slovenian streams. J Hydrol Hydromech 63:134-144

Birsan MV, Zaharia L, Chendes V, Branescu E (2014) Seasonal trends in Romanian streamflow. Hydrol Process 28:4496-4505

Chełmicki W (1991) Położenie, podział i cechy dorzecza. In: Dynowska I, Maciejowski M (eds) Dorzecze górnej Wisły. Część I, PWN Warszawa, pp 15-29
Chełmicki W, Skąpski R, Soja R (1999) Reżim hydrologiczny rzek karpackich w Polsce, Folia Geogr., Geogr.-Phys., Kom. Nauk Geogr. PAN, Kraków 29/30:67-8

Chen Z, Grasby SE (2009) Impact of decadal and century-scale oscillations on hydroclimate trend analyses. J Hydrol 365:122-133

Czaja S (1988) Zmiany stosunków wodnych w zlewni Brynicy w wyniku gospodarczej działalności człowieka. Geogr Stud Disser 11:60-93

Dobija A (1981) Sezonowa zmienność odpływu w zlewni górnej Wisły (po Zawichost). Zeszyty Naukowe UJ, Prace Geograficzne 53:51-112

Dobija A, Dynowska I (1975) Znaczenie parametrów fizjograficznych zlewni dla ustalenia wielkości odpływu rzecznego. Folia Geogr Ser Geogr Phys 9:77-127

Dynowska I (1971) Typy reżimów rzecznych w Polsce. Zeszyty Naukowe UJ, Prace Geograficzne 28:1-133

Dynowska I (1984) Zmiana reżimu odpływu w wyniku oddziaływania zbiorników retencyjnych. Czasop Geogr 55(3):301-315

Fal B, Bogdanowicz E (2002) Zasoby wód powierzchniowych Polski. Wiad IMiGW 25(2):3-38

Gutry-Korycka M (1996) Długookresowe tendencje elementów obiegu wody w zlewni w istniejących i w przewidywanych warunkach zmian globalnych klimatu. In: Gutry-Korycka M (ed) Studia nad wpływem globalnych zmian klimatu na obieg wody. Wydział Geografii i Studiów Regionalnych UW, Warszawa, p 159

Gutry-Korycka M (1997) Próba oceny odpływu rzek polskich w XXI wieku. Annales UMCS, Sectio B, Lublin 52(8):123-132

Hannaford J, Buysl G, Stahl GK, Tallaksen LM (2013) The influence of decadal-scalevariability on trends in long European streamflow records. Hydrol Earth Syst Sci 17:2717-2733

Jokiel P, Kożuchowski K (1989) Zmiany wybranych charakterystyk hydroklimatycznych Polski w bieżącym stuleciu. Dokumentacja Geograficzna IGPZ PAN 6:7-87

Kożuchowski K, Marciniak M (1992) Kontynentalizm termiczny klimatu na obszarze Polski w okresie 1881-1980. Wiad IMGW 15(4):89-93

Kundzewicz ZW (ed) (2012) Changes in flood risk in Europe, Special IAHS Publication, 10, Wallingford, Oxfordshire, UK

Kundzewicz ZW, Robson AJ (2004) Change detection in hydrological records-a review of the methodology. Hydrol Sci J 49:7-19

Lindstrom G, Bergstrom S (2004) Runoff trends in Sweden 18072002. Hydrol Sci 49(1):69-83

Madsen H, Lawrence D, Lang M, Martinkova M, Kjeldsen TR (2014) Review of trend analysis and climate change projections of extreme precipitation and floods in Europe. J Hydrol 519:3634-3650

McCabe GJ, Wolock DM (2002) A step increase in streamflow in the conterminous United States. Geophys Res Lett 29:2189

Miler A (1999) Okresowość i trendy czasowe zmian przepływów Warty w Poznaniu w okresie udokumentowanych obserwacji 1822-1997. In: Chełmicki W, Pociask-Karteczka J (eds) Interdyscyplinarność w badaniach dorzecza. IGUJ, Kraków, pp 99-107

Milly PCD, Betancourt J, Falkenmark M, Hirsch RM, Kundzewicz ZW, Lettenmaier DP, Stouffer RJ (2008) Stationarity is dead: whither water management? Science 319:573-574

Milly PCD, Betancourt J, Falkenmark M, Hirsch RM, Kundzewicz ZW, Lettenmaier DP, Stouffer RJ, Dettinger MD, Krysanova V (2015) On critiques of "Stationarity is dead: whither water management?'. Water Resour Res 51(9):7785-7789

Parajka J, Kohnova S, Merz R, Szolgay J, Hlavcova K, Blöschl G (2009) Comparative analysis of the seasonality of hydrological characteristics in Slovakia and Austria. Hydrol Sci J 54(3):456-473 
Pekarova P, Miklanek P, Pekair J (2003) Spatial and temporal runoff oscillation analysis of the main rivers of the world during the 19th-20th centuries. J. Hydrology 274:62-79

Piniewski M, Szczęśniak M, Mezghani A, Kundzewicz ZW (2016) Hydroclimatic projections for the Upper Vistula Basin. In: Kundzewicz ZW, Stoffel M, Niedźwiedź T, Wyżga B (eds) Flood risk in the Upper Vistula Basin. GeoPlanet: Earth and planetary sciences. Springer, Berlin, pp 331-339

Piniewski M, Szcześniak M, Kundzewicz ZW, Mezghani A, Hov Ø (2017) Changes in low and high flows in the Vistula and the Odra basins: model projections in the European-scale context. Hydrol Process 31(12):2210-2225

Piniewski M, Marcinkowski P, Kundzewicz ZW (2018) Trend detection in river flow indices in Poland. Acta Geophys 66(3):347-360

Pociask-Karteczka J (2006) River hydrology and the North Atlantic oscillation: a general review. AMBIO J Hum Environ 35(6):312-314

Pociask-Karteczka J (2016) Vistula basin-A geographical overview. In: Kundzewicz ZW, Stoffel M, Niedźwiedź, Wyżga B (eds) Flood risk in the Upper Vistula Basin. GeoPlanet: earth and planetary sciences. Springer, Berlin, pp. 3-21

Pociask-Karteczka J, Limanówka D, Nieckarz Z (2002-2003) Wpływ oscylacji północnoatlantyckiej na przepływy rzek karpackich (1951-2000). Folia Geogr Ser Geogr Phys 33-34:89-104

Punzet J (1973) Wpływ zbiorników retencyjnych na prawdopodobieństwo występowania wielkich wód w dorzeczu Górnej Wisły. Gosp Wodna 2:46-49

Romanowicz RJ, Kundzewicz ZW, Meresa HK, Stoffel M, Krysanova V, Doroszkiewicz J (2016) Projections of changes in flood hazard in two headwater catchments of the Vistula in the context of European-scale studies. In: Kundzewicz ZW, Stoffel M, Niedźwiedź T, Wyżga B (eds) Flood risk in the Upper Vistula Basin. GeoPlanet: earth and planetary sciences. Springer, Berlin, pp 341-359

Slater LJ, Singer MB, Kirchner JW (2015) Hydrologic versus geomorphic drivers of trends in flood hazard. Geophys Res Lett 42:370-376

Soja R (2002) Hydrologiczne aspekty antropopresji w polskich Karpatach. Prace Geograficzne 186:7-130
Stachý J (2010) Zmienność odpływu rocznego Odry i Wisły w latach 1901-2008. Monografie Komitetu Inżynierii Środowiska PAN 69:43-53

Stahl K, Hisdal H, Hannaford J, Tallaksen L, Van Lanen HAJ, Sauquet E, Demuth S, Fendekova M, Jordar J (2010) Streamow trends in Europe: evidence from a dataset of near-natural catchments. Hydrol Earth Syst Sci 14:2367-2382

Stahl K, Tallaksen LM, Hannaford J, Van Lanen HAJ (2012) Filling the white space on maps of European runoff trends: estimates from a multi-model ensemble. Hydrol Earth Syst Sci 16:2035-2047

Styszyńska A, Tamulewicz J (2005) Warta river discharges in Poznań and atmospheric circulation in the North Atlantic region. Quaest Geogr 23:63-81

Svensson C, Hannaford J, Kundzewicz ZW, Marsh T (2006) Trends in river floods: why is there no clear signal in observations? In: Frontiers in flood research: proceedings of kovacs colloquium, Paris, June 2006, vol 305. IAHS Publication, Wallingford, UK, pp 1-18

Wrzesiński D (2009) Tendencje zmian przepływu rzek Polski w drugiej połowie XX wieku. Badania fizjograficzne nad Polską Zachodnią, seria A-Geografia Fizyczne 60:147-162

Wrzesiński D (2011) Regional differences in the influence of the North Atlantic Oscillation on seasonal river runoff in Poland. Quaest Geogr 30(3):127-136

Wrzesiński D (2017) Reżim rzek Polski. In: Jokiel P, Marszelewski W, Pociask-Karteczk J (eds) Hydrologia Polski. Wyd. Naukowe PWN, Warszawa, pp 215-222

Wrzesiński D, Paluszkiewicz R (2011) Spatial differences in the impact of the North Atlantic Oscillation on the flow of rivers in Europe. Hydrol Res 42(1):30-39

Wrzesiński D, Sobkowiak L (2018) Detection of changes in flow regime of rivers in Poland. J Hydrol Hydromech 66(1):55-64

Yue S, Pilon P, Phinney B, Cavadias G (2002) The influence of autocorrelation on the ability to detect trend in hydrological series. Hydrol Process 16:1807-1829

Ziemońska Z (1973) Stosunki wodne w Polskich Karpatach Zachodnich. Prace Geograficzne PAN 103:124-127 